\title{
Correction to: The relation between reflection and the quality of a preschool teacher's education performance
}

\section{Zora Syslová* (i)}

The original article can be found online at https://doi. org/10.1186/s40723-0190060-y.

\section{${ }^{*}$ Correspondence:}

syslova@ped.muni.cz Department Primary

Education, Faculty

of Education of Masaryk

University, Porríčí 31, 603

00 Brno, Czech Republic

\section{Correction to: Int J Child Care Educ Policy (2019) 13:4}

https://doi.org/10.1186/s40723-019-0060-y

The original article contains a minor typo in Fig. 1; 'dodactic' should instead state 'didactic'.

Furthermore, the author wishes to acknowledge the source of this figure in this Correction article, detailed in Ref. (Píšová et al. 2013) here.

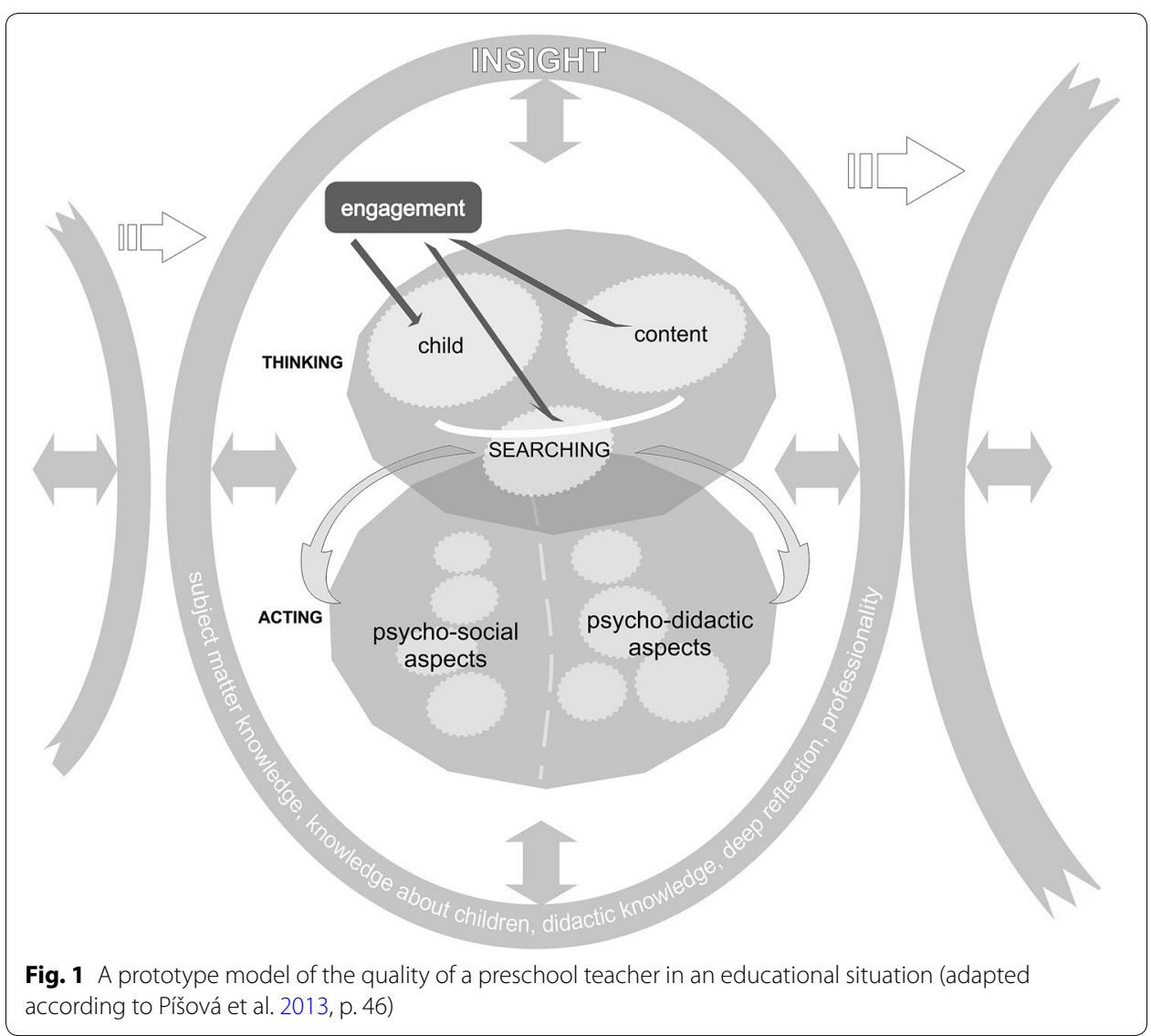

(c) The Author(s) 2020. This article is licensed under a Creative Commons Attribution 4.0 International License, which permits use, sharing, adaptation, distribution and reproduction in any medium or format as long as you give appropriate credit to the original author(s) and the source, provide a link to the Creative Commons licence, and indicate if changes were made. The images or other third party material in this article are included in the article's Creative Commons licence, unless indicated otherwise in a credit line to the material. If material is not included in the article's Creative Commons licence and your intended use is not permitted by statutory regulation or exceeds the permitted use, you will need to obtain permission directly from the copyright holder. To view a copy of this licence, visit http://creativeco mmons.org/licenses/by/4.0/ 
Published online: 24 March 2020

\section{References}

Pí̌̌ová, M., Hanušová, S., Kostková, K., Janíková, V., Najvar, P., \& Tưma, F. (2013). Učitel expert, jeho charakteristiky a determinanty profesního rozvoje (na pozadi výuky cizich jazykü). Brno: Muni Press.

\section{Publisher's Note}

Springer Nature remains neutral with regard to jurisdictional claims in published maps and institutional affiliations.

Submit your manuscript to a SpringerOpen ${ }^{\circ}$ journal and benefit from:

Convenient online submission

- Rigorous peer review

- Open access: articles freely available online

- High visibility within the field

- Retaining the copyright to your article

Submit your next manuscript at $>$ springeropen.com 